\title{
Trace elements determination by ICP-QMS in octopus edible samples from Mexico City markets
}

L.V.R. Saldívar-Osorio, ${ }^{1}$ M.T.J. Rodríguez-Salazar, ${ }^{1, *}$ M. L. Soubran-Zamora, ${ }^{1}$ C.E. Márquez-Herrera, ${ }^{1}$ M.E. Castilla-Madrigal, ${ }^{1}$ M.G. Espejel-Maya, ${ }^{1}$ M.A. Z. Arruda, ${ }^{2}$ and F. Barbosa-Jr. ${ }^{3}$

1 Laboratorio de Espectroscopia de Absorción Atómica, Departamento de Química Analítica, División de Estudios de Posgrado, Facultad de Química, Universidad Nacional Autónoma de México, Ciudad Universitaria, Coyoacán, 04510, México.mayte6900@gmail.com

2 Instituto Nacional de Ciência e Tecnologia em Bioanalítica, Universidade Estadual de Campinas (Unicamp), Cidade Universitária Zeferino Vaz Campinas, Barão Geraldo, Campinas, São Paulo, Brazil.

3 Department of Clinical, Toxicological and Bromatological Analysis, Faculty of Pharmaceutical Sciences of Ribeirão Preto, University of São Paulo, São Paulo, Brazil

Received January 22, 2013; Accepted July 19, 2013.

\begin{abstract}
The purpose of this study was to evaluate the total concentration levels of trace elements $(\mathrm{Cr}, \mathrm{Cu}, \mathrm{Mn}, \mathrm{Pb}, \mathrm{Rb}$ and $\mathrm{Sr})$ in octopus' mantle and tentacles samples from Mexico City markets, by using the Mexican regulation applied to food for human consumption. The determination of both essential $(\mathrm{Cr}, \mathrm{Cu}, \mathrm{Mn})$ and non-essential $(\mathrm{Pb}, \mathrm{Rb}$ and $\mathrm{Sr}$ ) trace elements was made by inductively coupled plasma-quadrupole mass spectrometry (ICP-QMS). The samples were collected from local markets and supermarkets from each of 16 delegations of Mexico City, Distrito Federal. The overall ranges of concentrations found were: $2.4-4.8,5.1-95.3,1-6,0.1-1.6,0.4-4.5$ and $11-58 \mathrm{mg} / \mathrm{kg}$ for $\mathrm{Cr}, \mathrm{Cu}, \mathrm{Mn}, \mathrm{Pb}, \mathrm{Rb}$ and $\mathrm{Sr}$, respectively. The maximum and mean concentration values obtained for $\mathrm{Cu}$ and $\mathrm{Cr}$ in mantle and tentacle samples from both kind of markets, are above of the NOM-051-SCFI/ SSA1-2010 (closest Mexican standard), according to USDA National NDB for Standard Reference consumer exposure (100g/day) of octopus. It was observed that the maximum $\mathrm{Pb}$ concentration value found in mantle and tentacle samples from supermarkets origin exceeds the NOM-129-SSA1-1995 and NOM-242-SSA1-2009 reference values, while the maximum mean value is below the regulation. Similar Mexican regulation data for $\mathrm{Mn}, \mathrm{Rb}$ and $\mathrm{Sr}$ were not found.

Keywords: Trace elements, octopus, cephalopods, ICP-QMS, Mexico City.
\end{abstract}

\section{Introduction}

Metals that are nutritionally essential for humans are $\mathrm{Co}, \mathrm{Cr}$, $\mathrm{Cu}, \mathrm{Fe}, \mathrm{Mg}, \mathrm{Mn}, \mathrm{Mo}$, Se and Zn. Fairbrother et al. [1] suggest that risk assessors should consider the essential elements as comprising three groups: those that are cations ( $\mathrm{Zn}, \mathrm{Fe}, \mathrm{Cu}, \mathrm{Mn}$, $\mathrm{Cr}$ ), those that are anions (Mo, Se), and those that are a bioinorganic complex (i.e., the Co complex, cobalamin). Excess amounts of essential metals can result in adverse effects to the homeostatic mechanisms of an organism. Specific biochemical functions have not been yet known for some elements, among them: Al, Br, Cd, Ge, Pb, Li, Rb and $\mathrm{Sn}$ [2].

Recently, Guérin et al. [3] mentioned the attention paid to the study of essential and toxic trace elements content in
Resumen. El objetivo del presente estudio fue evaluar el nivel de concentración total de elementos traza $(\mathrm{Cr}, \mathrm{Cu}, \mathrm{Mn}, \mathrm{Pb}, \mathrm{Rb}$ y $\mathrm{Sr})$ en muestras de manto y tentáculos de pulpo, recolectadas en mercados de la Ciudad de México, mediante la comparación con la normatividad mexicana aplicada en alimentos para consumo humano. La determinación de elementos traza esenciales $(\mathrm{Cr}, \mathrm{Cu}$ y $\mathrm{Mn})$ y no-esenciales $(\mathrm{Pb}, \mathrm{Rb}$ y $\mathrm{Sr})$ se llevó a cabo mediante espectrometría de masas con fuente de plasma de acoplamiento inductivo y analizador de masas cuadrupolo (ICP-QMS). Las muestras se recolectaron en mercados fijos y tiendas de supermercado, en cada una de las 16 delegaciones de la Cd. de México, Distrito Federal. Los rangos de concentraciones encontradas fueron: $2.4-4.8,5.1-95.3,1-6,0.1-1.6,0.4-4.5$ y $11-58 \mathrm{mg} /$ $\mathrm{kg}$ para $\mathrm{Cr}, \mathrm{Cu}, \mathrm{Mn}, \mathrm{Pb}, \mathrm{Rb}$ y $\mathrm{Sr}$, respectivamente. Los valores máximo y mínimo de concentración obtenidos para $\mathrm{Cu}$ y $\mathrm{Cr}$, en muestras de manto y tentáculo de pulpo recolectadas en ambas clases de mercados, fueron superiores a los correspondientes a la NOM-051-SCFI/SSA12010 (normatividad mexicana más relacionada). Esto, considerando el valor de referencia para exposición al consumidor de pulpo (100g/día) indicado por el USDA NDB. Las muestras de manto y tentáculo de pulpo, recolectadas en los supermercados, mostraron que el valor máximo de concentración de $\mathrm{Pb}$ excede los valores de referencia establecidos por las NOM-129-SSA1-1995 y NOM-242-SSA1-2009. Mientras que el valor promedio máximo es inferior a la normatividad mencionada. No se encontraron datos de normatividad mexicana para $\mathrm{Mn}, \mathrm{Rb}$ y $\mathrm{Sr}$.

Palabras clave: elementos traza, pulpo, cefalópodos, ICP-QMS, Ciudad de México.

foodstuffs because of the health benefits and risks of food consumption $[4,5,6,7]$. Toxicologists tend to regard seafood as a major vector for toxic substances such as metal trace elements because many marine organisms have the potential to bioconcentrate high levels of metals from their environment $[8$, $9,10,11]$. For example, Lourenço et al. [12], mentioned that little is known about the function of $\mathrm{Sr}$ and $\mathrm{Rb}$ in organisms, but the results of a few studies indicate that cephalopods may constitute a good source of Sr. Thus, there is an open research field in this area.

The pollution of the oceans or the continental waters, results from the spill of hundreds of million tons of residues and wastewaters coming from urban sites and farming lands. Besides, great amounts of chemical substances are found in preda- 
tor species, as a result of the biomagnification (concentration of the chemical substances in the levels superiors of the trophic chain). These concentrations also are consequences of the bioaccumulation of chemical substances in tissues, throughout the life of the organism. For example, a large fish (representing older age) will have a higher content of a chemical substance than a small fish of the same species [13].

Mollusks have an important role to play in the ecosystem, varying from the herbivorous chitons feeding on microalgae and seaweeds attached to rocks, to the specialist carnivores like octopuses feeding on individual crab species. The mollusks have high nutritious value, since they contain vitamins A, B and $\mathrm{D}$, carbohydrates and proteins in suitable amounts and of easy digestion [14]. Cephalopods are a highly nutritious, because of lack of bones, the average edible part of these organisms is between 80 and $85 \%$ of the total body [15]. The cephalopods reproduce once in their life and they are characterized by their small life cycle. They are active predators having a determining role in the trophic chain in the oceans and they are also an important fishing resource [16]. Several studies have evaluated the capacity of cephalopods to accumulate trace elements [12, $17,18,19,20]$. In general, feeding is considered the primary pathway for trace elements bioaccumulation in cephalopod [21]. Due to their rapid growth and market price, the culture of cephalopods has been an increasing area of interest [22]. Therefore, octopus can constitute a significant source of essential elements for man but also represents a source of exposure to toxic elements.

In Mexico, the fishing is an important resource to provide food for the inhabitants [23]. The octopus capture represents the fourth place in fishing activities at the coast of the Gulf of Mexico and the Caribbean (the capture of fish, shrimp and oyster are the most important). The capture of the octopus includes mainly two species: red octopus (Mayan octopus) and the common octopus (Octopus vulgaris). The 95 percentage of the octopus capture comes from the states of Yucatan, Campeche, Quintana Roo and Veracruz [24].

Thus, there is need to asses the trace elements concentrations in this food product, in order to evaluate the relationships between adverse effects observed in humans because of the dietary exposure. Martins et al. [25] have evaluated even the different cooking methods (grilling, frying and boiling) on selenium content of marine species commonly consumed in Portugal.

Methods used to trace elemental characterization of biological materials include: atomic absorption spectrometry (AAS), inductively coupled plasma atomic emission spectrometry (ICPAES), inductively coupled plasma mass spectrometry (ICPMS), particle induced x-ray emission (PIXE), neutron activation analysis (NAA) and energy dispersive $x$-ray fluorescence (EDXRF) [4, 26, 27]. In Mexico, different AAS techniques (flame, FAAS; graphite furnace, GFAAS; hydride generation, HGAAS and cold vapor, CVAAS) have been recommended by the Mexican Official Standards NOM-117- SSA1-1994 [28] and PROY-NOM-211-SSA1-2002 [29] for the analysis of As, $\mathrm{Hg}, \mathrm{Ag}, \mathrm{Cd}, \mathrm{Cr}, \mathrm{Cu}, \mathrm{Fe}, \mathrm{Ni}, \mathrm{Pb}, \mathrm{Se}, \mathrm{Sn}$ and/or $\mathrm{Zn}$ in water, ice and food and additives for human consumption.
Nowadays, the use of ICP-MS is becoming more common in determination of essential and toxic elements concentration levels in consumed food products $(3,22,27)$. Compared to graphite furnace atomic absorption spectrometry (GFAAS) or ICP-AES, this technique has some advantages: simultaneous multielement measurement capability, high sensitivity, linear dynamic range, characterized spectral interferences and rapid mass scanning [27].

The aim of the present study was to determine the total concentration levels of essential trace elements $(\mathrm{Cr}, \mathrm{Cu}$ and $\mathrm{Mn})$ and non-essential elements ( $\mathrm{Pb}, \mathrm{Rb}$ and $\mathrm{Sr}$ ) by ICP-QMS in octopus edible tissues (mantle and tentacle) consumed in Mexico City, Distrito Federal. And to evaluate and to compare the results obtained with available Mexican reference values. Samples were collected from local markets and supermarkets from each of 16 delegations of the Distrito Federal, where the supermarkets represent the 52 percentage as the biggest local supplier of foodstuffs [30].

\section{Experimental Procedure}

The samples of octopus Octopus vulgaris (wet weight between $1.0-2.5 \mathrm{~kg}$ ) were collected from one supermarket and one local market of each Mexico City delegation (see the sampling zone on Fig. 1). The samples were washed with deionized water, cutted off in small pieces and dried in oven to constant weight. About 0.11-0.14 g of dry weight of tentacle and mantle samples of each octopus were digested in a microwave oven (Provecto Analítica Jundiaí, model DGT 100 plus) using $2 \mathrm{~mL}$ concentrated $\mathrm{HNO}_{3}$ and $1 \mathrm{~mL} \mathrm{H} \mathrm{H}_{2} 30 \%$. Digested samples were diluted to $10 \mathrm{~mL}$ in a volumetric flask. Analytical quantification of the isotopes ${ }^{52} \mathrm{Cr},{ }^{63} \mathrm{Cu},{ }^{55} \mathrm{Mn},{ }^{208} \mathrm{~Pb},{ }^{85} \mathrm{Rb}$ and ${ }^{88} \mathrm{Sr}$ was performed by ICP-QMS (Perkin-Elmer, model Elan DRC-II). This instrument is equipped with Meinhard concentric nebulizer connected to a cyclonic spray chamber. A radiofrequency of $1100 \mathrm{~W}$ power was selected in pulse mode. Sample data were acquired by using 20 sweeps/reading, one reading/replicate, and a dwell time of $50 \mathrm{~ms}$. High purity de-ionized water (resistivity $18.2 \mathrm{M} \Omega \mathrm{cm}$ ) used in sample and solution preparation was obtained using a Milli-Q water purification system (Millipore RiOs-DITM). All reagents used were of analyticalreagent grade except for nitric acid, which had been previously purified in a quartz sub-boiling still Kürner Analysentechnik) before use. The certified reference material (CRM) employed was IAEA V-10 (International Atomic Energy Agency), and ${ }^{103} \mathrm{Rh}$ was used as internal standard.

\section{Results and Discussion}

Table 1 shows the comparison of the measured values obtained for $\mathrm{Cr}, \mathrm{Cu}, \mathrm{Mn}, \mathrm{Pb}, \mathrm{Rb}$ and $\mathrm{Sr}$ with the certified values provided by the CRM IAEA V-10. Detection limit (LOD) is also presented for each analyzed element in this study. The relative error percentage values obtained were in descending order of 


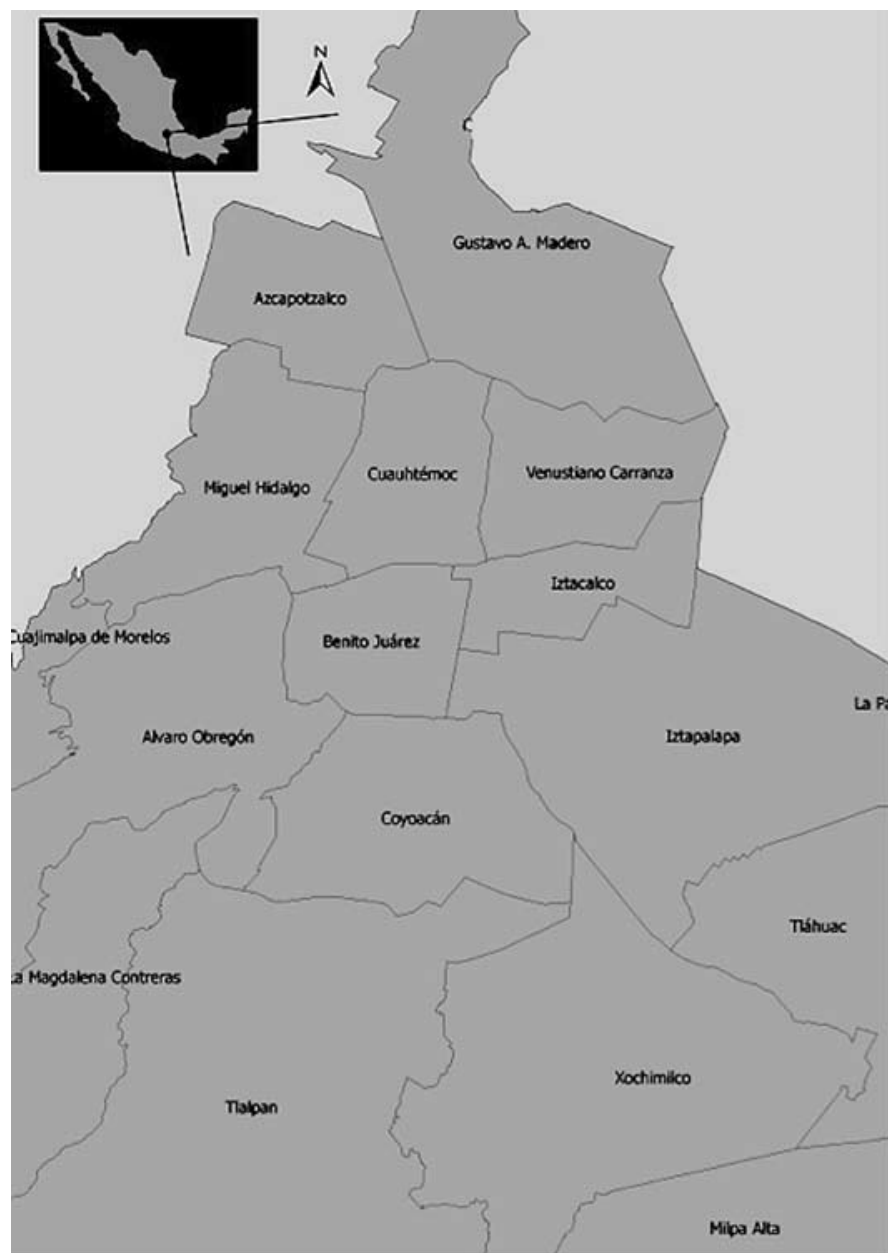

Fig. 1. Sampling zone. Mexico City, Distrito Federal and its sixteen delegations (Azcapotzalco, Alvaro Obregón, Benito Juárez, Coyoacán, Cuauhtémoc, Cuajimalpa de Morelos, Gustavo A. Madero, Iztacalco, Iztapalapa, Magdalena Contreras, Miguel Hidalgo, Milpa Alta, Tláhuac, Tlalpan, Venustiano Carranza and Xochimilco).

accuracy: $1.5,1.9,-4.5,6.6,-9.1$. and $-18.4 \%$ for $\mathrm{Sr}, \mathrm{Mn}, \mathrm{Cu}$, $\mathrm{Cr}, \mathrm{Rb}$ and $\mathrm{Pb}$, respectively. Likewise, the LOD values (in $\mathrm{ng} / \mathrm{g}$ ) observed in descending order of analytical sensitivity were: 0.2 for $\mathrm{Cr}$ and $\mathrm{Pb} ; 0.4$ for $\mathrm{Rb}$ and $\mathrm{Sr} ; 0.5$ for $\mathrm{Mn}$ and $1.2 \mathrm{ng} / \mathrm{g}$ for $\mathrm{Cu}$. The analytical results were in good agreement with the certified values and below the acceptance criteria reported for elemental analysis in biological matrices $[5,31,32]$. The experimental procedure was reliable for analyzing the octopus samples.

\section{Essential elements $(\mathrm{Cr}, \mathrm{Cu}$ and $\mathrm{Mn})$}

Chromium helps to maintain normal blood glucose levels, but its adverse effects of excessive consumption leads to chronic renal failure [33]. There are genetic diseases related to copper's metabolism: Menkes' kinky-hair disease related to copper deficiency, and Wilson's disease presented by copper in excess [34]. Symptoms of toxicity by manganese are the development of schizophrenia with nervous disorders similar to Parkinson's disease. Lower manganese blood levels have been observed in patients with osteoporosis, non-trauma epilepsy and Perthes' disease [35].

Table 2 presents the range and mean values for total concentrations $(\mathrm{mg} / \mathrm{kg})$ of essential elements $(\mathrm{Cu}, \mathrm{Cr}$ and $\mathrm{Mn})$ determined in mantle and tentacles octopus samples. This table also shows the closest Mexican regulation NOM-051-SCFI/ SSA1-2010 [36] values for $\mathrm{Cr}$ and $\mathrm{Cu}$. The range and mean calculated values obtained for $\mathrm{Cr}$ were similar in all kind of samples (mantle and tentacle from local and supermarkets). The minimum and maximum concentration values were: 2.4 $\mathrm{mg} / \mathrm{kg}$ and $4.8 \mathrm{mg} / \mathrm{kg}$, respectively. The maximum mean value obtained for $\mathrm{Cr}$ was $3.6 \mathrm{mg} / \mathrm{kg}$. For $\mathrm{Mn}$, a total concentration value of $1 \mathrm{mg} / \mathrm{kg}$ was obtained as a minimum and $6 \mathrm{mg} / \mathrm{kg}$ as the highest concentration observed, specially for mantle samples from supermarket origin. The maximum mean concentration value was $2 \mathrm{mg} / \mathrm{kg}$ (for all kind of samples, except for tentacle samples from local market). While for $\mathrm{Cu}$ it was observed appreciable differences in maximum range and mean values for mantle samples from both kind of markets. The minimum and maximum range concentration values were: $5.1 \mathrm{mg} /$ $\mathrm{kg}$ (mantle samples from local market) and $95.3 \mathrm{mg} / \mathrm{kg}$ (mantle samples from supermarket), respectively. The maximum mean concentration value obtained was: $29.8 \mathrm{mg} / \mathrm{kg}$ (mantle samples from supermarket).

The experimental results of this research were compared with studies performed in Africa by Soldevilla [37]; in Monaco by Miramand and Guary [18]; and in Portugal by Lourenço et al. [12], Seixas et al. [21] and Napoleão et al. [38]. The mean concentration values reported for $\mathrm{Cu}$ in descending order were: $81,36,30$ and $22.4 \mathrm{mg} / \mathrm{kg}$ for Seixas et al. [21], Soldevilla [37], Napoleão et al. [38] and Lourenço et al. [12]; and the maximum mean value for this work was $29.8 \mathrm{mg} / \mathrm{kg}$. All values are similar, except for the highest mean concentration value from Seixas et al. [21]. It can be noted that a high value was also found in this study, in mantle from supermarket (95.3 $\mathrm{mg} / \mathrm{kg}$ ). The data reported for $\mathrm{Mn}$ mean concentration values were in descending order: $3,2.39,2.2,1.82$ and $1.8 \mathrm{mg} / \mathrm{kg}$ for Miramand and Guary [18], Seixas et al. [21], Soldevilla [37], Lourenço et al. [12] and Napoleão et al. [38]; while the maximum mean concentration result of this work was $2 \mathrm{mg} / \mathrm{kg}$. No marked differences were noted among the country sampling and/or collection zones.

The results obtained for $\mathrm{Cr}$ and $\mathrm{Cu}$ determination were compared with the existing Mexican regulations related to the content of heavy metals in food for human consumption (Table 2). According to the NOM-051-SCFI/SSA1-2010 standard [36], the reference nutrition values are set as $0.022 \mathrm{mg} / \mathrm{day}$ for $\mathrm{Cr}$ and $0.65 \mathrm{mg} /$ day for $\mathrm{Cu}$, as daily intake suggested. The maximum total concentration values obtained for $\mathrm{Cr}$ and $\mathrm{Cu}$ in samples from supermarket are above of these regulations $(0.48$ $\mathrm{mg}$ /day for $\mathrm{Cr}$ in mantle and tentacle samples; and $9.53 \mathrm{mg} / \mathrm{day}$ for $\mathrm{Cu}$ in mantle samples), regarding the amount of consumption $(100 \mathrm{~g} /$ day) information from USDA National NDB for Standard Reference, NDB15166 [39]. There were not found Mexican regulation values for $\mathrm{Mn}$.

Data from USDA NDB15166 [39] indicating the amount in $100 \mathrm{~g}$ (amount of consumption per day) of edible portion of 
Table 1. Results for certified reference material $(\mathrm{CRM})^{\mathrm{a}}$ and limits of detection for trace elements analyzed by ICP-QMS.

\begin{tabular}{ccccc}
\hline Element & $\begin{array}{c}\text { Certified value, } \\
\mathrm{mg} / \mathrm{kg} \\
\left(95 \% \text { C.I. }^{\mathrm{b}}\right)\end{array}$ & $\begin{array}{c}\text { Experimental value, } \\
\mathrm{mg} / \mathrm{kg} \pm \mathrm{SD}^{\mathrm{c}}\end{array}$ & \% Relative error ${ }^{\mathrm{d}}$ & LOD $^{\mathrm{e}}, \mathrm{ng} / \mathrm{g}$ \\
$\mathrm{Cr}$ & $6.5(5.6-7.1)$ & $6.9 \pm 0.2$ & 6.6 & 0.2 \\
$\mathrm{Cu}$ & $9.4(8.8-9.7)$ & $9.0 \pm 0.1$ & -4.5 & 0.5 \\
$\mathrm{Mn}$ & $47(44-51)$ & $48 \pm 0.6$ & -18.4 & 0.2 \\
$\mathrm{~Pb}$ & $1.6(0.8-1.9)$ & $1.3 \pm 0.02$ & -9.1 & 0.4 \\
$\mathrm{Rb}$ & $7.6(7.3-7.8)$ & $6.9 \pm 0.1$ & 1.5 & 0.4 \\
$\mathrm{Sr}$ & $40(37-44)$ & $39 \pm 0.6$ & 1.5 \\
\hline
\end{tabular}

${ }^{a}$ CRM: IAEA V-10. ${ }^{\mathrm{b}}$ C.I.: Confidence Interval. ${ }^{\mathrm{c}} \mathrm{SD}$ : Standard deviation. ${ }^{\mathrm{d}} \%$ Relative error $=(($ mean experimental value - certified value $) /$ certified value) $100 .{ }^{\text {e }}$ LOD: Limit of detection.

Table 2. Range and mean values of total concentration for essential elements $(\mathrm{Cu}, \mathrm{Cr}$ and $\mathrm{Mn})$ in mantle and tentacle octopus samples from Mexico City markets. Data of Mexican regulation.

\begin{tabular}{|c|c|c|c|c|c|c|}
\hline \multirow[t]{3}{*}{ Element } & \multicolumn{4}{|c|}{ Range $\left(\right.$ Mean $\left.\pm \mathrm{SD}^{\mathrm{a}}\right), \mathrm{mg} / \mathrm{kg}$} & \multirow{3}{*}{$\begin{array}{c}\text { Maximum } \\
\text { concentration } \\
\text { (maximum } \\
\text { mean), mg/day }\end{array}$} & \multirow{3}{*}{$\begin{array}{c}\text { Mexican } \\
\text { regulation } \\
{[36], \mathrm{SDI}^{\mathrm{e}} \text {, }} \\
\mathrm{mg} / \text { day }\end{array}$} \\
\hline & \multicolumn{2}{|c|}{ Mantle $^{\mathrm{b}}$} & \multicolumn{2}{|c|}{ Tentacle $^{\mathrm{c}}$} & & \\
\hline & Supermarket & Local market & Supermarket & Local market & & \\
\hline $\mathrm{Cu}$ & $11.9-95.3(29.8 \pm 23.1)$ & $5.1-92.0(29.4 \pm 26.6)$ & $5.6-46.0(14.3 \pm 9.2)$ & $5.8-17.1(12.0 \pm 3.5)$ & $9.53^{\mathrm{f}}(2.98)^{\mathrm{f}}$ & 0.65 \\
\hline $\mathrm{Mn}$ & $1-6(2 \pm 1.2)$ & $1-3(2 \pm 0.6)$ & $1-3(2 \pm 0.6)$ & $1-2(1 \pm 0.3)$ & $0.60^{f}(0.20)^{f, g, h}$ & \\
\hline
\end{tabular}

${ }^{\mathrm{a}} \mathrm{SD}$ : Standard deviation. ${ }^{\mathrm{b}}$ Number of samples $(n)=16 .{ }^{\mathrm{c}} n=15 .{ }^{\mathrm{d}}$ Regarding the consumer exposure (100g/day) for octopus edible samples, information from USDA National NDB for Standard Reference [39]. ${ }^{\mathrm{e}}$ SDI: Suggested daily intake. ${ }^{\mathrm{f}}$ Content found in octopus mantle samples from supermarket. ${ }^{\mathrm{g}}$ Content found in octopus tentacle samples from supermarket. ${ }^{\mathrm{h}}$ Content found in octopus mantle samples from local market.

octopus have established the values for $\mathrm{Cu}(0.435 \mathrm{mg} / 100 \mathrm{~g}$ or $0.435 \mathrm{mg} /$ day $)$, and for $\mathrm{Mn}(0.025 \mathrm{mg} / 100 \mathrm{~g}$ or $0.025 \mathrm{mg} /$ day $)$. According to this, the maximum values obtained for the samples analyzed in this research exceeds the values established by the NDB15166 [39]. Values were: $9.53 \mathrm{mg} /$ day for $\mathrm{Cu}$, and 0.6 $\mathrm{mg}$ /day for Mn. Both values were obtained in the analysis of mantle samples from supermarket. Other reported regulations data for $\mathrm{Cr}, \mathrm{Cu}$ and $\mathrm{Mn}$ are reported on Table 3. The values obtained were compared as mg/day unities. And, the comparison allowed to notice that the maximum experimental values obtained in this research, exceed the values recommended by the American Society Nutrition, ASN [40] and National Academies [41] for $\mathrm{Cr}$ and $\mathrm{Cu}$.

\section{Non-essential elements $(\mathbf{P b}, \mathbf{R b}, \mathbf{S r})$}

The main exposure route to lead in nonoccupationally exposed individuals is by food consumption [42]. Its toxicity results in anemia, kidney damage and central nervous abnormalities [2]. Rubidium is physiologically similar to potassium $[2,43]$ and it has been found in high levels in malignant and benign thyroid nodules [44]. The replacement of calcium by strontium because of their similar behaviors, originates osseous mineralization disorders $[45,46]$.

Table 4 displays the range and mean values for total concentrations $(\mathrm{mg} / \mathrm{kg})$ found for the analytical determination of non-essential elements $(\mathrm{Pb}, \mathrm{Rb}, \mathrm{Sr})$, in mantle and tentacles octopus samples, consumed in the sampling zone. The range and mean calculated values obtained for $\mathrm{Rb}$ were similar in all kind of samples (mantle and tentacle from local and supermarkets). The minimum and maximum concentration values were: $0.4 \mathrm{mg} / \mathrm{kg}$ and $4.5 \mathrm{mg} / \mathrm{kg}$, respectively. The maximum mean value obtained for $\mathrm{Rb}: 2.1 \mathrm{mg} / \mathrm{kg}$. For $\mathrm{Pb}$, a total concentration value of $0.1 \mathrm{mg} / \mathrm{kg}$ was obtained as a minimum and $1.6 \mathrm{mg} / \mathrm{kg}$ as the highest concentration observed, specially for tentacle samples from supermarket origin. The maximum mean concentration value was: $0.5 \mathrm{mg} / \mathrm{kg}$ (for mantle and tentacle samples from supermarket). While for $\mathrm{Sr}$ it was observed appreciable differences in maximum range value for mantle samples from supermarket. The minimum and maximum range concentration values were: $11 \mathrm{mg} / \mathrm{kg}$ (mantle and tentacle samples from local market) and $58 \mathrm{mg} / \mathrm{kg}$ (mantle samples from supermarket), respectively. The maximum mean concentration value obtained was: $21 \mathrm{mg} / \mathrm{kg}$ (mantle samples from local market).

The results obtained in this work were compared with data reported by Lourenço et al. [12], Raimundo et al. [47] and Seixas et al. [21]. All of them performed in Portugal coasts. Maximum concentration value reported by Lourenço et al. [12] for $\mathrm{Sr}$ was $27.7 \mathrm{mg} / \mathrm{kg}$, this value is below the corresponding data obtained in this research: $58 \mathrm{mg} / \mathrm{kg}$. Similar data were noted for $\mathrm{Rb}$ from Lourenço et al. [12] $(4.29 \mathrm{mg} / \mathrm{kg})$, and for the value obtained by this study $(4.5 \mathrm{mg} / \mathrm{kg})$. While for $\mathrm{Pb}$, 
Table 3. Reported regulation data for essential elements $(\mathrm{Cu}, \mathrm{Cr}$ and $\mathrm{Mn})$.

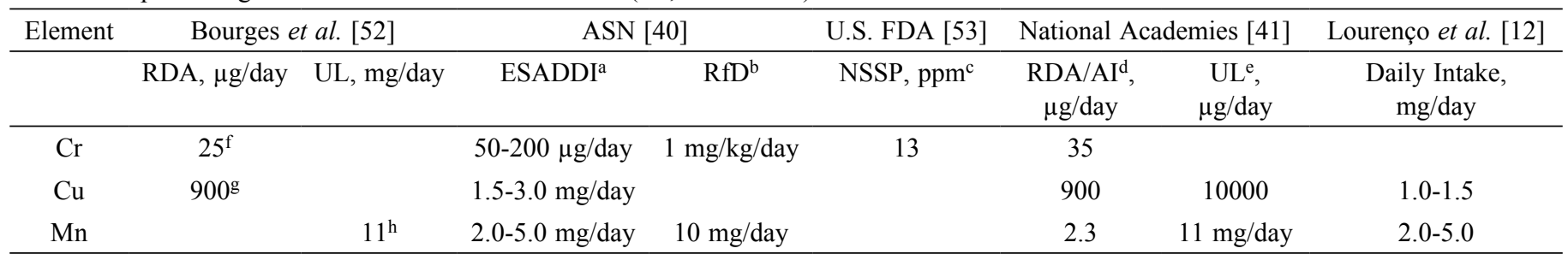

a ESADDI: Estimated Safe and Adequate Daily Dietary Intake for adults. ${ }^{\mathrm{b}}$ RfD: Reference Dose. ${ }^{\mathrm{c}}$ NSSP: National Shellfish Sanitation Program. Tolerances and guidance values for poisonous or deleterious substances in seafood. ${ }^{\mathrm{d}}$ RDA/AI: Recommended Dietary Allowances / Adequate Intakes. ${ }^{\mathrm{e}}$ UL: Tolerable Upper Intake Levels. ${ }^{\mathrm{f}}$ Suggested for adults (19-50 years old). ${ }^{\mathrm{g}}$ Recommended for adults. ${ }^{\mathrm{h}}$ For adults $(\geq$ 19 years old).

Table 4. Range and mean values of total concentration for non-essential elements $(\mathrm{Pb}, \mathrm{Rb}$ and $\mathrm{Sr})$ in mantle and tentacles octopus samples from Mexico City markets. Data of Mexican regulation.

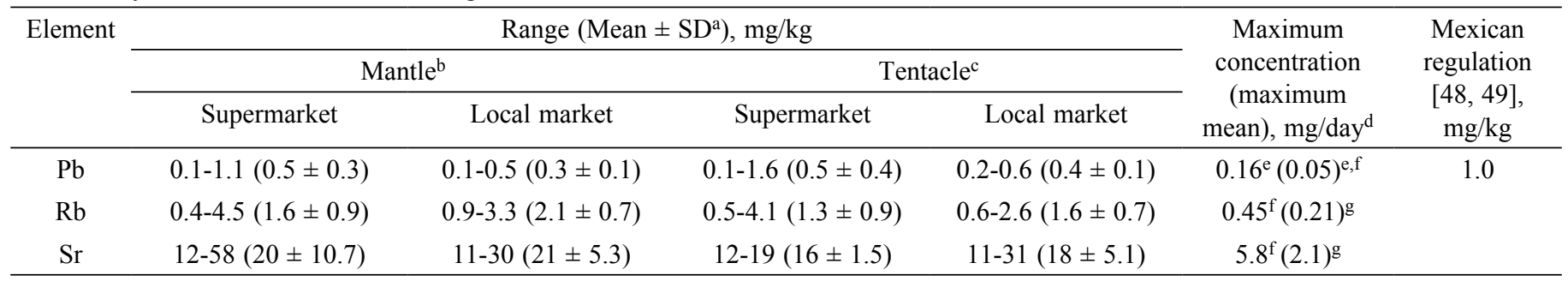

${ }^{\mathrm{a}} \mathrm{SD}$ : Standard deviation. ${ }^{\mathrm{b}}$ Number of samples $(n)=16 .{ }^{\mathrm{c}} n=15 .{ }^{\mathrm{d}}$ Regarding the consumer exposure (100 g/day) for octopus edible samples, information from USDA National NDB for Standard Reference [39]. ${ }^{\mathrm{e}}$ Content found in octopus tentacle samples from supermarket. ${ }^{\mathrm{f}}$ Content found in octopus mantle samples from supermarket. ${ }^{\mathrm{g}}$ Content found in octopus mantle from local market.

the concentration value reported were in descending order: 4, 2.3 and $0.24 \mathrm{mg} / \mathrm{kg}$ from Seixas et al. [21], Raimundo et al. [47] and Lourenço et al. [12], respectively. There is noted that value reported by Seixas et al. [21] is appreciable higher than the maximum concentration value found by this research: $1.6 \mathrm{mg} / \mathrm{kg}$. No appreciable differences were noted among the sampling and/or collection zones for each country (Portugal or Mexico).

In comparison with the reference values established for NOM-129-SSA1-1995 [48] and NOM-242-SSA1-2009 [49], maximum value obtained for $\mathrm{Pb}$ total concentration $(1.6 \mathrm{mg} /$ $\mathrm{kg}$ in octopus tentacle samples from supermarkets) exceeds the regulation value $(1 \mathrm{mg} / \mathrm{kg})$ (Table 4). No data exist for $\mathrm{Rb}$ and $\mathrm{Sr}$. Other reported regulations data for $\mathrm{Pb}, \mathrm{Rb}$ and $\mathrm{Sr}$ are reported on Table 5. In a similar way, previously done for essential elements, the comparison was made in $\mathrm{mg}$ /day. The maximum experimental values obtained for $\mathrm{Pb}$ and $\mathrm{Sr}$ exceed the value given by the ASN [40] and the regulation values (as daily intake) mentioned by Lourenço et al. [12].

\section{Comparison of trace elements levels among purchase place of the octopus samples}

The trace element data from mantle and tentacles of octopus samples obtained for each purchase place are presented in Figure 2. The total concentration leves of $\mathrm{Cr}$ are similar in both mantle and tentacle samples, and among the supermarket and local purchase market from Mexico City where they were col- lected. The highest values found were: $95.3 \mathrm{mg} / \mathrm{kg}$ for $\mathrm{Cu}$ in mantle sample from northern supermarket located in Venustiano Carranza (V.C.) delegation, $6 \mathrm{mg} / \mathrm{kg}$ for $\mathrm{Mn}$ in mantle sample from supermarket at northern delegation Gustavo A. Madero (G.A.M.), $1.6 \mathrm{mg} / \mathrm{kg}$ for $\mathrm{Pb}$ tentacle sample purchased at supermarket from western delegation Miguel Hidalgo (M.H.) delegation, $4.5 \mathrm{mg} / \mathrm{kg}$ for $\mathrm{Rb}$ in mantle sample from supermarket origin situated at western Delegation Alvaro Obregón (A.O.) and $58 \mathrm{mg} / \mathrm{kg}$ for $\mathrm{Sr}$ in mantle samples collected at supermarket located at southern Xochimilco (X.) delegation. As it was mentioned previously, the highest values were obtained for mantle samples collected at supermarkets, although it is required a larger sample size than this preliminary study to identify clearly possible "hotspot" purchase place.

The overall evaluation of the results of this work was interpreted as presence of several metal contribution sources in the organisms analyzed, with higher accumulation on octopus mantle samples from supermarket origin. By their part, Miramand and Bentley [17]; Seixas et al. [21]; Seixas and Pierce [20] and Villanueva and Bustamante [22], have reported that mainly the digestive gland and branchial heart appeared to play a major role in bioaccumulation process of toxic elements. These organs are located at the mantle of these marine organisms. It is worthy to mention that the several sources of metal contribution (from the sea to the distribution markets), for the analyzed samples in this survey, were not identified.

Recently, the Mexican Government has announced the creation of the Aquaculture Program, which promotes the 
Table 5. Reported regulation data for non-essential elements ( $\mathrm{Pb}, \mathrm{Rb}$ and $\mathrm{Sr})$.

\begin{tabular}{cccc}
\hline Element & ASN [40] & U.S. FDA [53] & Lourenço et al. [12] \\
\hline $\mathrm{Pb}$ & Typical daily dietary intake & NSSPa, $\mathrm{ppm}$ & Daily Intake, mg/day \\
$\mathrm{Rb}$ & $15-100 \mu \mathrm{g} /$ day & 1.7 & \\
$\mathrm{Sr}$ & $1-5 \mathrm{mg} /$ day & & $1-5$ \\
\hline
\end{tabular}

a NSSP: National Shellfish Sanitation Program. Tolerances and guidance values for poisonous or deleterious substances in seafood.
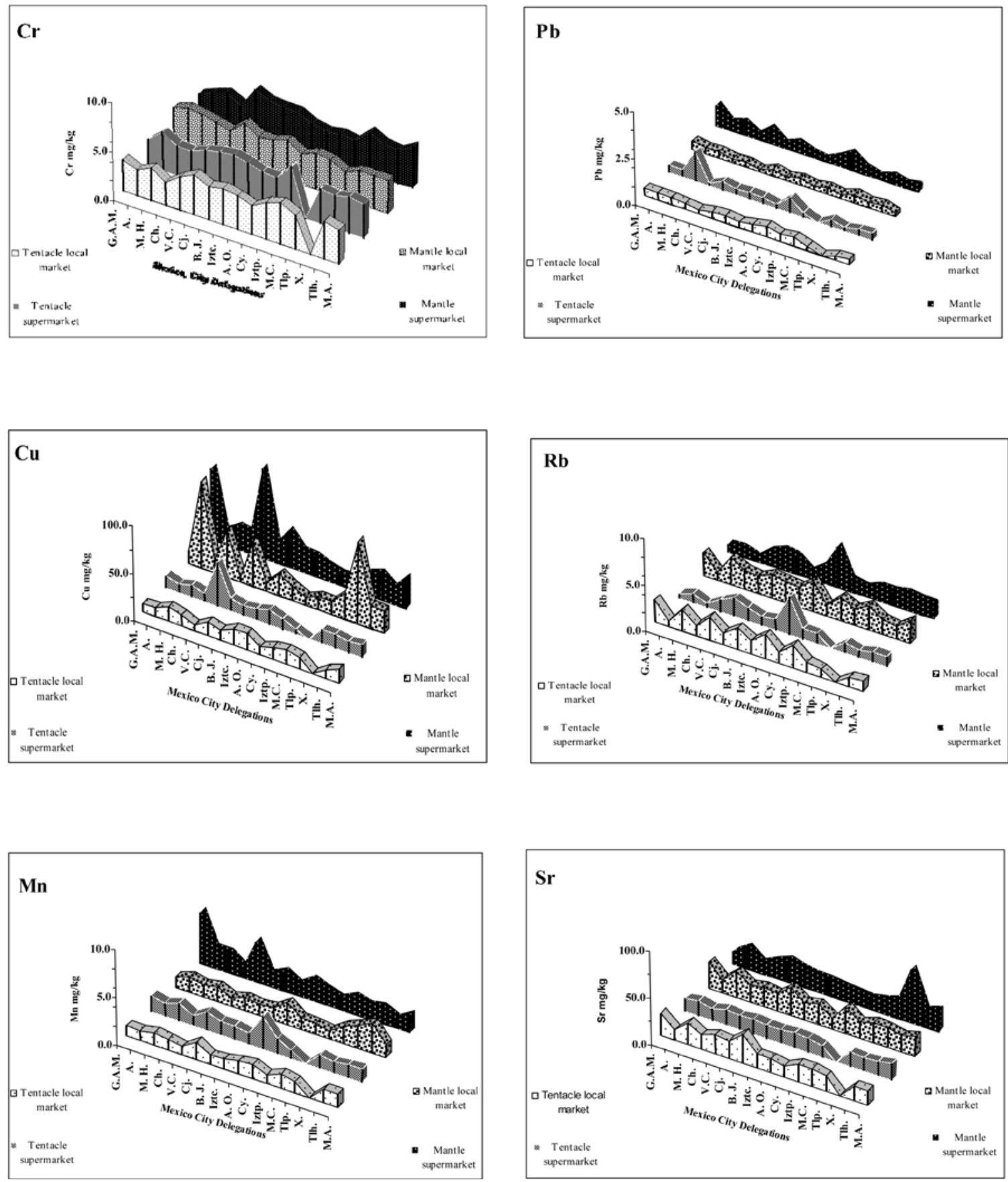

Fig. 2. Total concentration of trace elements in octopus samples collected in sixteen delegations from Mexico City, Distrito Federal. From north to south are: G.A.M. (Gustavo A. Madero), A. (Azcapotzalco), M.H. (Miguel Hidalgo), Ch. (Cuauhtémoc), V.C. (Venustiano Carranza), Cj. (Cuajimalpa de Morelos), B.J. (Benito Juárez), Iztc. (Iztacalco), A.O. (Alvaro Obregón), Cy. (Coyoacán), Iztp. (Iztapalapa), M.C. (Magdalena Contreras), Tlp. (Tlalpan), X. (Xochimilco), Tlh. (Tláhuac) and M.A. (Milpa Alta). 
adequate sustainability of the fishing resources of our country and the reproduction of species with biological and economic importance in the Mexican diet [50]. This program proposed the aquaculture as a good alternative to minimize the excessive exploitation effects of fishing and to guarantee the existence of its products (fish, shrimp, oyster and octopus) in the markets, as well as a good economical employment cycle [23, 24,51]. This assay could be useful to help authorities make decisions about the regulations in metal content and distribution of octopus from the sea to the consumer table.

\section{Conclusions}

This research provides information related to the total concentration levels found for essential trace elements $(\mathrm{Cr}, \mathrm{Cu}$, $\mathrm{Mn})$ and non-essential elements $(\mathrm{Pb}, \mathrm{Rb}, \mathrm{Sr})$, in the octopus mantle and tentacles samples collected in the sixteen delegations into which Mexico City, Distrito Federal is divided. The comparison was established with the available Mexican regulation related to the content of heavy metals in food for human consumption. According to the results, it was concluded that the maximum and mean concentration values obtained for $\mathrm{Cr}$ $(0.48 \mathrm{mg} /$ day $)$ and $\mathrm{Cu}(9.53 \mathrm{mg} /$ day, $)$, especially in mantle samples from supermarket, exceed the reference nutrition values given by NOM-051-SCFI/SSA1-2010 standard (0.022 y $0.65 \mathrm{mg} /$ day for $\mathrm{Cr}$ and $\mathrm{Cu}$, respectively). Whereas for $\mathrm{Pb}$, the comparison was made regarding NOM-129-SSA1-1995 and NOM-242-SSA1-2009 standards. It was observed that the maximum concentration value obtained for this element especially for tentacle samples, from supermarkets origin (1.6 $\mathrm{mg} / \mathrm{kg}$ ) exceeds the Mexican regulation $(1.0 \mathrm{mg} / \mathrm{kg})$. While the maximum $\mathrm{Pb}$ mean concentration value $(0.05 \mathrm{mg}$ /day) was below the regulation $(0.1 \mathrm{mg} /$ day $)$.

The above was interpreted as a bioaccumulation signal of $\mathrm{Cr}, \mathrm{Cu}$ and $\mathrm{Pb}$ in the octopus edible parts analyzed especially from supermarket origin. These findings should constitute an effective and necessary current measure of assessing the adequacy and safety of seafoods consumed in Mexico City, and may be a basis for future monitoring studies for total elemental concentration levels and to trace or to identify contribution metal sources.

Although there is not Mexican regulation data for $\mathrm{Mn}$, $\mathrm{Rb}$ and $\mathrm{Sr}$, the results were compared with other international reference nutrition standards. The maximum total concentration value obtained for $\mathrm{Mn}$ in mantle samples from supermarket origin $(0.6 \mathrm{mg} /$ day $)$ exceeds the values established by the USDA NDB15166 for Mn $(0.025 \mathrm{mg} /$ day $)$, although the value meets requirements established by ASN (2.0-5.0 mg/day) and National Academies (11 mg/day). The maximum total concentrations value obtained for $\mathrm{Sr}$ in mantle samples from supermarket (5.8 mg/day), exceed Daily Intake value (1-5 mg/day) reported. The highest values found in this work, particularly for $\mathrm{Mn}, \mathrm{Sr}, \mathrm{Pb}$ and $\mathrm{Rb}$; correspond to supermarkets located at northern delegation Gustavo A. Madero, southern delegation
Xochimilco and westerns delegations Miguel Hidalgo and Alvaro Obregón, respectively.

This work could be helpful for further research in food chemistry and regulation area to establish preventive safety and health measures, although is required a larger sample size than this preliminary study.

\section{Acknowledgments}

The authors would like to thank to Víctor Tapia-Cruz for map edition, Imelda Velázquez M. (Bibliographic Information Services Department), and Rafael Ibarra (English Publishing Instructor) from Faculty of Chemistry, UNAM. This research was partially supported by DGAPA-UNAM projects (PAPIIT IN229911, PAPIME 201211 and PAL 3400-02).

\section{References}

1. Fairbrother, A.; Wenstel., R.; Sappington, K.; Wood, W. Ecotoxicol. Environ. Safety 2007, 68, 145-227.

2. Nielsen, F.H.; Dunn, M. American Society for Nutrition. Available on: http://jn.nutrition.org/nutinfo/, accessed in 2010

3. Guérin, T.; Chekri, R.; Vastel, C.; Sirot, V.; Volatier, J.; Leblanc, J.; Noël, L. Food Chem. 2011, 127, 934-942.

4. Choi, M.; Kang, M.; Kim, M. Biol. Trace Elem. Res. 2009, 128, 104-117.

5. Millour, S.; Noël, L.; Kadar, A.; Chekri, R.; Vastel, C.; Guérin, T. J. of Food Comp. Anal. 2011, 24, 111-120.

6. Nasreddine, L.; Nashalian, O.; Naja, F.; Itani, L.; Parent-Massin, D.; Nabhani-Zeidan, M.; Hwalia, N. Food Chem. Toxicol. 2010, $48,1262-1269$.

7. Tapia, J.; Vargas-Chacoff, L.; Bertrán, C.; Carrasco-G.; Torres, F.; Pinto, R.; Urzúa, S.; Valderrama, A.; Letelier, L. Food Chem. 2010, 121, 666-671.

8. Ahdy, H.H.H.; Abdallah, A.M.A.; Tayel, F.T. Egypt. J. Aq. Res. 2007, 33, 85-97.

9. Erkan, N.; Özden, Ö.; Ulusoy, S. Food Anal. Meth. 2011, 4, 35-40.

10. Nghia, N. D.; Lunestad, B. T.; Trung, T.S.; Son, N. T.; Maage, A. Bull. Environ. Contam. Toxicol. 2009, 82, 75-79.

11. Obirikorang, K.A.; Amisah, S.; Adjei-Boateng, D.; Madkour, H.A.; Otchere, F.A. Bull. Environ. Contam. Toxicol. 2010, 85, 497-501.

12. Lourenço, H.M.; Anacleto, P.; Afonso, C.; Ferraria, V.; Martins, M.F.; Carvalho, M.L.; Lino, A.R.; Nunes, M.L. Food Chem. 2009, 113, 1146-1153.

13. Food and Agriculture Organization of the United Nations, FAO. Assurance of seafood quality. Italy. Available on: http://www. fao.org/DOCREP/003/T1768S/T1768S04.htm\#ch3.6, accessed in 2010.

14. Luna-Raya, M.C.; Urciaga-García, J. I.; Salinas-Zavala, C. A.; Cisneros-Mata; M. A., Beltrán-Morales; L. F. Economía. Sociedad y Territorio 2006, VI, 535-560.

15. Arvanitoyannis, I.; Varzakas, T. Int. J. Food Sci. Technol. 2009, 44, 58-78.

16. Rosas, C.; Caamal, C.; Cázares, R.; Rodríguez, D.; Romero, M.; Chay, D. Manual preliminar para el cultivo de pulpo Octopus maya. Secretaria de Desarrollo Rural y Pesca. Gobierno de Yucatán, Facultad de Ciencias, Universidad Nacional Autónoma de México, Yucatán, México, 2006. 
17. Miramand, P.; Bentley, D. Marine Biology 1992, 114, 407-414.

18. Miramand, P.; Guary, J.C. Bull. Environ. Contam. Toxicol. 1980, 24, 783-788.

19. Perugini, M.; Visciano, P.; Manera, M.; Zaccaroni, A.; Olivieri, V.; Amorena, M. Bull. Environ. Contam. Toxicol. 2009, 83, 244248.

20. Seixas, S.; Pierce, G. Water, Air and Soil Poll. 2005, 163, $137-$ 152.

21. Seixas, S.; Bustamante, P.; Pierce, G.J. Chemosphere 2005, 59, 1113-1124.

22. Villanueva, R.; Bustamante, P. Aquaculture 2006, 261, 225-240.

23. Instituto Nacional de la Pesca, INAPESCA. México. Available on: http://www.inapesca.gob.mx/portal/sala-de-prensa/boletines/109fortalecen-al-inapesca-en-sus-tareas-a-favor-del-sector-alimentario-), accessed in 2011.

24. Instituto Nacional de la Pesca, INAPESCA-Secretaría de Agricultura, Ganadería, Desarrollo rural, Pesca y Alimentación, SAGARPA. Sustentabililidad y pesca responsable en México. Evaluación y Manejo, México, 2006.

25. Martins, C.T.; Almeida, C. M. M.; Alvito, P.C. Food Anal. Meth. 2011, 4, 77-83.

26. Mohapatra, A.; Rautray, T.R.; Vijayan, V.; Mohanty, R.K.; Dey, S.K. Aquaculture 2007, 270, 552-558.

27. Nardi, E.P.; Evangelista, F.S.; Tormen, L.; Saint'Pierre, T.D.; Curtius, A.J.; de Souzas, S.S.; Barbosa Jr., F. Food Chem. 2009, 112 727-732.

28. Secretaría de Salud. NOM-117- SSA1-1994. Goods and services. Testing method for the determination of cadmium, arsenic, lead, tin, copper, iron, zinc and mercury in food, potable water and purified water by atomic absorption spectroscopy. Official Gazette of the Federation, México, 1994.

29. Secretaría de Salud. PROY-NOM-211-SSA1-2002. Goods and services. Physical-chemical testing methods. Determination of humidity and total solids in food by oven drying. Determination of arsenic, cadmium, copper, chromium, tin, iron, mercury, nickel, silver, lead, selenium and zinc in food, water and ice for human consumption, food additive by atomic absorption spectroscopy. Official Gazette of the Federation, México, 2002.

30. Asamblea Legislativa del Distrito Federal. IV Legislatura (2008). Versión estenográfica de la sesión celebrada el día 30 de julio de 2008. México. 2008.

31. DeSilva, B.; Smith, W.; Weiner, R.; Kelley, M.; Smolec, J.M.; Lee, B.; Khan, M.; Tacey, R.; Hill, H.; Celniker, A. Pharmaceutical Res. 2003, 20, 1885-1900.

32. Millour, S.; Nöel, L. ; Chekri, R.; Vastel. C.; Kadar, A.; Guérin, T. Accred. Qual.Assur., 2010, 15, 503-513.

33. Anderson, R.; Stoecker, B. American Society for Nutrition. Available on: http://jn.nutrition.org/nutinfo/, accessed in 2010

34. Medeiros, D.M; Percival, S.S. American Society for Nutrition. Available on: http://jn.nutrition.org/nutinfo/, accessed in 2010.

35. Freeland-Graves, J.; Johnson, P. American Society for Nutrition. Available on: http://jn.nutrition.org/nutinfo/, accessed in 2010.

36. Secretaría de Economía-Secretaría de Salud. NOM-051-SCFI/
SSA1-2010. General labeling specifications for pre-packaged food and non-alcoholic drinks-commercial and sanitary information. Official Gazette of the Federation, México, 2010.

37. Soldevilla, F.L. Alimentaria 1987, 33, 33-7.

38. Napoleão, P.; Pinheiro, T.; Sousa, C. R. Sci. Total Environ. 2005, 345, 41-49.

39. United States Department of Agriculture (USDA). National Nutrient Database for Standard Reference, Release 23. Available on: http://www.ars.usda.gov/Services/docs.htm?docid=8964, accessed in 2010.

40. American Society for Nutrition (ASN). Available on: http:// jn.nutrition.org/nutinfo//, accessed in 2010.

41. National Academies. Food and Nutrition Board, Institute of Medicine. Available on: http://www.nap.edu/, accessed in 2010.

42. Medeiros, R.J.; dos Santos, L.M.G.; Freire, A.S.; Santelli, R.E.; Braga, A.M.C.B.; Krauss, T.M.; Jacob, S.C. Food Control 2012, 23, 535-541.

43. Báránya, E.; Bergdahlb, I.A.; Brattebyc, L.E.; Lundhd, T.; Samuelsonc, G.; Schützd, A.; Skerfvingd, S.; Oskarssona, A. Sci. Total Environ. 2002, 286, 129-141.

44. Amaral, A.F.S.; Arruda, M.; Cabral, C.; Rodrigues, A.S. Environment International 2008, 34, 1104-1108.

45. Millour, S.; Noël, L.; Chekri, R.; Vastel, C.; Kadar, A.; Sirot, V.; Leblanc, J.; Guerin, T. J. Food Comp. Anal. 2012 25, 108-129.

46. Polak-Juszczak, L. Chemosphere 2011, 83, 486-491.

47. Raimundo J.; Caetano M.; Vale C. Sci. Total Environ. 2004, 325, 71-81.

48. Secretaría de Salud. NOM-129- SSA1-1995. Goods and services. Fishery products: dry salted and smoked products; chilled and frozen cephalopod and gastropod mollusks. Health provisions and specifications. Official Gazette of the Federation, México, 1995.

49. Secretaría de Salud. NOM-242-SSA1-2009. Goods and services. Fresh, chilled, frozen and processed fishery products. Health specifications and test methods. Official Gazette of the Federation, México, 2009.

50. Instituto Nacional de la Pesca, INAPESCA. México. Available on: http://www.inapesca.gob.mx/portal/component/content/article/17publicaciones/167-crece-inversion-en investigacionpesquera-enmexico, accessed in 2011.

51. Instituto Nacional de la Pesca, INAPESCA. México. Available on: http://www.inapesca.gob.mx/portal/sala-de-prensa/destacadas/171-impulsaran-desarrollo-de-tecnologia-en-unidades-de-produccion-acuicola, accessed in 2011

52. Bourges R., H. ; Casanueva, E.; Rosado, J.L. Recomendaciones de ingestión de nutrimentos para la población mexicana. Ed. Médica Panamericana, S.A. de C.V., México, 2005.

53. U.S. Food and Drug Administration (FDA). Tolerances and guidances levels for poisonous or deleterious substances in seafood. National Shellfish sanitation programa . Guide for the control of molluscan shellfish. Available on: http://www.fda.gov/ Food/FoodSafety/ProductSpecificInformation/Seafood/FederalStatePrograms/NationalShellfishSanitationProgram/UCM053987, accessed in 2010. 